\title{
Does violence pay? The effect of ethnic rebellion on overcoming political deprivation
}

Conflict Management and Peace Science 2016, Vol. 33(I) 3-24

(C) The Author(s) 2014

Reprints and permissions: sagepub.co.uk/journalsPermissions.nav DOI: $10.1177 / 07388942 \mid 4559670$ cmp.sagepub.com

\section{Carlo Koos}

German Institute of Global and Area Studies and University of Hamburg, Germany

\begin{abstract}
Studies have found that politically deprived groups are more likely to rebel. However, does rebellion increase the likelihood of achieving political rights? This article proposes that rebellion helps ethnic groups to overcome deprivation. I illustrate this by using a "typical" case (the ljaw's struggle against the Nigerian government) to demonstrate how ethnic rebellion increases the costs for the government to a point where granting political rights becomes preferable to war. Further, I exploit time-series-cross-sectional data on deprived ethnic groups to show that rebellion is significantly associated with overcoming deprivation. The statistical analysis shows that democratic change is an alternative mechanism.
\end{abstract}

\section{Keywords}

Asymmetric warfare, civil war, ethnic rebellion, political deprivation, strategic bargaining

\section{Introduction}

Research on ethnic conflict has largely focused on the determinants of why ethnic groups rebel. The relative deprivation of groups has been viewed as a major cause of violent uprisings (Gurr, 1970). Recent studies have found strong empirical support for horizontal inequalities between and the deprivation of ethnic groups within a society being robustly associated with civil wars (Cederman et al., 2010, 2011; Østby et al., 2009; Østby, 2008; Stewart, 2008).

Remarkably, most of these studies appear to implicitly share a particular view on the function of violent rebellions: an ethnic group's rebellion is a strategy to improve the group's political status. Of course this assumption makes sense, as groups will only resort to violence if they expect that the benefits of rebelling will outweigh the costs. However, this claim has received surprisingly little explicit scholarly attention. As Mack (1975: 175-176) noted almost 40 years ago, "In the field of conflict research, the study of the outcome and the conduct of wars, as against that of their etiology, has received remarkably little attention. The outcome

\section{Corresponding author:}

Carlo Koos, German Institute of Global and Area Studies, Research Programme 2, Violence and Security, Neuer Jungfernstieg 2I, Hamburg, 20354, Germany.

Email: carlo.koos@giga-hamburg.de 
of 'asymmetric conflicts'... has been almost totally neglected". Since then, the theoretical and empirical literature has clearly grown extensively, but research on the effectiveness of rebellions has not.

This article contributes toward filling this gap and asks whether rebellions by deprived ethnic groups help to overcome political deprivation. Violent rebellions and civil wars are bloody endeavors that disrupt and traumatize societies, sometimes for even two or three generations. Considering the bloodshed and atrocities associated with civil wars, rebellions are hardly ever efficient. Yet are they effective - that is, do they put governments under enough pressure so that they at some point grant the rebel groups political rights?

In this article I propose that violent rebellions are an effective tool for deprived ethnic groups to overcome deprivation and attain political rights. Theoretically, when governments deprive particular ethnic groups within a nation, they do so intentionally - not accidentally. By depriving ethnic groups, governments exclude them from engaging in conventional political channels and drive them toward violent rebellion (e.g. Gurr, 2000: 157). Hence, violent rebellion becomes a viable alternative for deprived groups.

History has witnessed plenty of politically excluded ethnic groups that have resorted to violence against the state and have succeeded in overcoming their deprivation. One example is the Ijaw's violent conflict with the Nigerian government and the subsequent nomination of Goodluck Jonathan as vice president. Another example is the struggle of South Sudanese ethnic groups against the Sudanese government, which led to autonomy arrangements, government representation and finally independence. There are plenty of other examples of how rebel ethnic groups have achieved political rights after (often enduring) violent struggles.

These groups would have known that warfare would be costly and that the state security forces would be militarily stronger. Nevertheless, that knowledge did not stop any of these weaker groups from rebelling. Of course, not all rebelling groups win against the state; victory, however, may not actually be the objective. The target of overcoming deprivation and achieving political rights is more modest than that of defeating the state and the groups in power. By rebelling, ethnic groups - often implicitly - aim at increasing the costs of deprivation to the point where granting political rights becomes cheaper to those in power.

To test the argument that ethnic rebellion helps groups to overcome deprivation, this paper uses information from the ETH Ethnic Power Relations 2.0 (EPR-ETH) dataset (Cederman et al., 2010). Utilizing time-series-cross-section data on the political status of ethnic groups, I find robust support for the claim that previous rebellions were associated with overcoming deprivation and achieving political rights.

This article continues as follows: I introduce the relevant literature, outline the theoretical line of reasoning (i.e. when and why rebellion works) and derive the hypothesis. I then use the case of the Ijaw in Nigeria to illustrate the logic of the argument, after which I introduce the statistical analysis of ethnic groups' access to political power. I then present my conclusion and discuss the wider implications of my findings.

\section{Political deprivation as a cause of ethnic rebellion}

A large body of research on the grievances-conflict link dating back at least to Gurr's (1970) relative deprivation theory posits that deprived groups within a society are more likely to take up arms against the state. "Deprivation" can be understood as the outright 
discrimination against ethnic groups or, less extremely, as the nonrepresentation of ethnic groups at the national or subnational level.

Political discrimination aims at depriving certain groups within a nation of fundamental political rights. Cederman et al. $(2010$ : 99,101$)$ argue, for instance, that political discrimination is "directly targeted at an ethnic community - thus disregarding indirect discrimination based, for example, on educational disadvantage or discrimination in the labor or credit markets". They add that "group members are subjected to active, intentional, and targeted discrimination, with the intent of excluding them from both regional and national power. Such active discrimination can be either formal or informal".

In the less extreme version of political deprivation, ethnic groups are powerless and "elite representatives hold no political power at either the national or the regional level without being explicitly discriminated against" (Cederman et al., 2010: 100). ${ }^{1}$

In both instances, outright discrimination and the more subtle denial of representation can cause frustration among ethnic groups, which can result in protest and even violent uprising. Although Gurr's deprivation theory had intuitive appeal, empirical evidence had largely not supported his argument (see, e.g. Brush, 1996). Only recently have studies measuring ethnic group's political access found empirical evidence that politically disadvantaged ethnic groups are more likely to rebel (Buhaug et al., 2013; Cederman et al., 2010, 2011). ${ }^{2}$ In this sense, engaging in rebellion is implicitly understood as a group's attempt to forcefully end a continuous state of deprivation. This is a straightforward and unsurprising understanding of the function of rebellion. However, what do we actually know about the effect that ethnic rebellion has on helping excluded groups to achieve political rights? At first glance, it would seem not that much.

\section{Theorizing ethnic rebellion as a path to political rights}

Although there is a lack of studies on whether ethnic rebellion actually helps deprived groups to achieve political rights, the extensive work on interstate wars, state building, strategic government-rebel interactions and nonviolent campaigns provides valuable insights into related aspects and similar processes. On a meta-level, there are those who argue that violence produces political power and remains an integral process of state building (Tilly, 1985). Some even claim that nonviolence only fills the gaps between phases of violence (Ginsberg, 2013). Mao's statement that "political power grows out the barrel of a gun" and Clausewitz's observation that "war is merely the continuation of policy by other means" exemplify this position.

These claims are contrasted by several newer studies that argue that nonviolent campaigns are better suited to achieving political objectives than violent ones (Chenoweth and Stephan, 2011; Shaykhutdinov, 2010; Stephan and Chenoweth, 2008). Nonviolent campaigns are considered more powerful because they enjoy moral superiority. Consequently, nonviolent movements can count on more international and domestic support. It is suggested that security forces would hesitate in cracking down on nonviolent protests. The puzzle, then, is why have so many groups resorted to violence?

Fearon and Laitin (2011: 199) claim that "the prevalence of ethnic civil wars has been increasing over time. Fifty-three percent of the 17 civil wars we code as breaking out in the years 1945-49 were ethnic. For the next six decades, the corresponding percentages are 74, $71,67,81,83$, and 100 (for 2000-08)". These figures do not directly imply that - in absolute 
numbers - more ethnic groups resort to violence, nor that only politically deprived groups are involved in ethnic civil wars. Rather, they illustrate that ethnic rebellions and infighting among ethnically divided governmental segments are far from uncommon. ${ }^{3}$ However, if nonviolence is more effective, why do so many ethnic groups engage in violence? Would it not be more effective for deprived ethnic groups to take to the streets to peacefully demand that their grievances be addressed?

Presumably, some deprived groups have initially pursued nonviolent means, which have been met by brute force by the state, thus setting a violent dynamic in motion. Although this runs against the "nonviolence works" argument, it is not uncommon for nondemocratic governments to crack down on nonviolent movements, with the aim of wiping out the rebellious momentum (Davenport, 1995) and setting an example for other potential protesting groups (Walter, 2006). This shows that not all governments care about moral superiority as suggested by the "nonviolence works" argument.

Whereas cracking down on a broadly supported nonviolent movement may have severe negative repercussions for the state (e.g. defection within the security forces, see Chenoweth and Stephan, 2011), the potential costs faced by the government for repressing a nonviolent campaign by a deprived ethnic group are likely to be smaller. In the latter scenario, a government (i.e. the representatives of the ethnic groups in power) could expect a less extreme backlash from its own ethnic support base as repression of "others" would be perceived as defending the "own" group's status. In such a context, governments may prefer to use suppression to establish a societal belief that nonviolent resistance by ethnic minorities is futile.

Yet, this strategy often backfires and instead makes the aggrieved groups aware that their tool of choice - namely, nonviolence - is ineffective. Once a group realizes that discrimination will not be overcome purely through conventional political channels and nonviolent protest, it may consider violent means and mobilize its members to fight against the state. Why would armed rebellion be an effective option for overcoming discrimination in such a situation? First and foremost, governments that deprive ethnic groups do so by choice-not by accident - in order to control and limit these groups' access to power and resources (see e.g. Davenport and Inman, 2012; Davenport, 1995; Levi, 1989). Without a strong reason to do so, those in power generally have little interest in granting concessions to such groups as this might create incentives for other groups to rebel as well (Mehler, 2009; Stedman, 1997; Toft, 2009: 43; Tull and Mehler, 2005).

Violent uprising might therefore become a viable option in order to achieve rights if nonviolent strategies have failed to yield the expected results or have been a poor tactic per se. Gurr (2000: 157) asks the following: "If rebellion is the last resort of those seeking minority rights and self-determination, does that imply that conventional politics is their first resort?" He answers, "Sometimes yes, but minorities often are closed out of conventional politics". Besides, minority groups may not be populous or centrally located enough to stage mass protests in the capital. Protests in peripheral areas can more easily be ignored by the central government than those in the center. Gurr further states that "if the political rules of the game exclude or marginalize ethnic and national minorities, then engaging in conventional politics constitutes a poor strategic choice for their leaders".

While - or rather because - violent uprising is a risky endeavor, it will demonstrate to the groups in power that the mobilized rebels are committed to their objective of overcoming discrimination, can mobilize recruits, have access to arms and are a threat to the state's monopoly on the use of violence at the local or even national level. For both sides (i.e. the state 
and the insurgents), the question of whether to engage in an armed struggle is a matter of weighing up the costs and benefits.

On paper, the military imbalance between a state and an insurgent movement would suggest that the state is always likely to win. Yet history shows that, in many asymmetric wars, the weaker party won. Referring to the Vietnam War, Mack (1975: 177) argues "that the simplistic but once prevalent assumption - that conventional military superiority necessarily prevails in war-has been destroyed". Arreguín-Toft (2005: 4) also points out that "weaker" actors have won $51 \%$ of all asymmetric wars since 1950. Buhaug (2006) adds that power asymmetry makes rebels pursue territorial autonomy rather than aiming to overthrow a government. In other words, a state's power does not wholly determine the outcome of a conflict, because other factors will play a significant role too.

What factors offset state military strength and allow an ethnic group to attain political rights? Much depends on the rebels' goal. If a group aims to defeat the state and its ruling elite, the chances of success will be very low in most cases. If, on the other hand, the goal is more modest - for example, to "only" achieve basic political rights and end group-targeted discrimination - there will be a greater chance of success. The strategy is rather to increase the pressure on and the costs for the state to such a degree that conferring political rights on the discriminated group is less costly than being at war with them.

In his seminal work on why big states lose small wars, Mack (1975) proposes the concept of relative interest as a critical factor for success in asymmetric wars. Weak actors, he argues, fight for survival and are therefore more determined to carry the costs of conflict, whereas stronger opponents have a comparably lower relative interest but higher costs - that is, public costs and the ruling elite's unwillingness to endure the high costs of long wars make strong actors succumb to the demands of the rebels. Mack (1975: 177) explains how weak actors can win politically without winning militarily:

In every case, success for the insurgents arose not from a military victory on the ground-though military successes may have been a contributory cause - but rather from the progressive attrition of their opponents' political capability to wage war. In such asymmetric conflicts, insurgents may gain political victory from a situation of military stalemate or even defeat.

More practical aspects matter too. Rebels enjoy several home-turf advantages if government troops are deployed to and warfare takes place in their territory. In the Art of War, Sun Tzu underlines the importance of knowing the territory:

The contour of the land is an aid to an army; sizing up opponents to determine victory, assessing dangers and distances, is the proper course of action for military leaders. Those who do battle knowing these will win, those who do battle without knowing these will lose.

Local rebels will know best where to hide and retreat because they will be more familiar with the particularities of the local terrain. Such knowledge provides them with advantages when setting up bases and training camps and organizing logistics. In contrast, government facilities and garrisons are often limited to urban hubs. It is therefore much harder for nonnative government troops to gather reliable intelligence on insurgency movements and plan counterinsurgency actions.

Often, rebel groups fighting for their ethnic community's cause can draw on substantial local support. This can have multiple causes. The local population may simply feel that its 
interests are represented best by the rebels. In addition, fear of retribution, selective violence by rebels for noncooperation and indiscriminate violence by government forces will affect cooperation with rebels (Kalyvas, 2006). As a result, the local population will provide the rebel group with support in terms of information (while misinforming government actors), food, labor, recruits and often even money. These support services by the local community are crucial to a rebel group's success (see e.g. Weinstein, 2005). Government forces, on the other hand, will encounter problems in distinguishing combatants from civilians and consequently face a disadvantage.

In short, taking their relative weakness into account, ethnic rebel groups' most effective option in terms of obtaining political rights or autonomy is not to overthrow a government, but to wear it and those in power down by attrition. Once the government realizes that the costs of warfare exceed the benefits of suppressing a group, they will consider ceasing discriminatory practices, grant political rights, provide a share of governmental power or negotiate autonomy arrangements. Of course, achieving political representation or autonomy does not automatically make ordinary members of an ethnic group profit from these arrangements. Rather, a group's political representation will depend on the quality of their representatives and the effectiveness of their election campaigns.

In the following section, I present qualitative evidence that demonstrates how the process chain of ethnic discrimination, state repression, violent rebellion and civil war leads to political rights.

\section{Qualitative accounts on the effectiveness of ethnic rebellion}

The struggle of the Ijaw minority in Nigeria's oil-rich Niger Delta is a typical case ${ }^{4}$ of how an ethnic rebellion can pressure the government into ceding political rights. The Ijaw are the largest ethnic minority in the Niger Delta. Since oil production began in the region in the $1950 \mathrm{~s}$, the area has been subject to large-scale environmental damage that has severely affected the livelihoods of local fishermen and farmers. Both fishing grounds and farmland have been destroyed by oil spills, but compensation payouts have been inadequate. At the same time, the local population has felt excluded from the financial benefits that the oil companies and the state have generated on its land. Taken together, these factors and the lack of political representation aggravated the Ijaw's grievances (see e.g. Ukiwo, 2011; Watts and Ibaba, 2011).

At the end of the 1990s, the Ijaw mobilized large-scale nonviolent protests and demanded more political representation and that their complaints be addressed by the federal government. The Ijaw Youth Council insisted that the Ijaw control Ijaw land and set an ultimatum to foreign oil companies to withdraw from their territory. The Nigerian state responded to these demands and nonviolent protests heavy-handedly, with security forces crushing public protests, shooting protesters and raiding villages in the area (Okonta and Douglas, 2003).

Even though Nigeria introduced democracy in 1999, the Ijaw believed that nonviolence would not help them to realize their goal. Building on broad support for their cause, the Ijaw leadership mobilized a violent campaign. The Niger Delta People's Volunteer Force and the Niger Delta Vigilante, the two largest Ijaw militias, spearheaded the struggle against the state. During the course of the Niger Delta conflict, a number of other militias emergedincluding the Movement for the Emancipation of the Niger Delta (Okonta and Douglas, 2003; Watts and Ibaba, 2011). 
Besides directly confronting the state via battles with security forces, the ethnic militias also indirectly targeted the government through various strategies. One such tactic was to exploit the Nigerian state's dependence on oil revenues by sabotaging oil-production infrastructures. This saw Nigerian oil output drop by $30 \%$, which had a severe impact on the state budget. Another strategy was to hack into pipelines and steal oil, commonly known as bunkering. Rebels also began kidnapping politicians, their families and foreign oil workers for ransom (Ukiwo, 2007). All of these methods resulted in massive costs to the Nigerian state.

The government's strategy of relying on military means only yielded a minor improvement to the security situation in the Niger Delta. In an attempt to address local grievances, the federal government created the Niger Delta Development Commission (NDDC) in 2000. The NDDC was mandated to improve social and environmental conditions in the region. However, it was popularly viewed as nothing more than a vehicle to embezzle funds. Even today the NDDC's track record on infrastructure development projects remains very modest (UNDP, 2006). Ultimately, the government's initiative had no effect on restoring peace.

For the Nigerian government, the conflict in the Niger Delta became increasingly costly. The ongoing attacks on oil facilities and large-scale oil theft seriously reduced government revenues. It was not until President Yar'Adua appointed Goodluck Jonathan (an ethnic Ijaw) as vice president in 2007 that the dynamic of the conflict changed for the better. Some observers believe that Vice President Jonathan's appointment was a strategic response to the unresolved armed conflict in the Niger Delta as the selection of an Ijaw vice president would be received positively by the Ijaw community and assure them that their grievances would be addressed (International Crisis Group, 2007).

Since taking office, Jonathan has been instrumental in facilitating the disarmament and demobilization of ethnic militias in the Niger Delta. He introduced an amnesty program that offered Ijaw militants in the Niger Delta a stipend of around US\$400 per month for turning in their weapons. Although the amnesty program was not designed to address the underlying root grievances of the Niger Delta, the level of violence dropped drastically after its introduction (Aghedo, 2012; Davidheiser and Nyiayaana, 2011). With the appointment of Goodluck Jonathan (an ethnic representative of the Ijaw) as vice president, the state's political promises became more credible. Although the Ijaw achieved political representation by one of their kin, the living conditions of most Ijaw have barely improved since then. Ethnic militia leaders and fighters were the prime beneficiaries of the newly found political resources and power.

To conclude, violent rebellion was not the Ijaw's first choice. Their initial efforts to effect change entailed several nonviolent campaigns that were crushed by the Nigerian state, which wanted to set an example that any uprising would fail. After the failure of nonviolent action, the Ijaw turned to violent campaigns in order to pressure the government to address their grievances. The Ijaw not only managed to overcome their political deprivation, but they also saw one of their representatives appointed as vice president.

Apart from the Ijaw and Nigeria, other ethnic rebel groups have experienced similar trajectories. The South Sudanese's long and violent struggle for political and economic participation against the Sudanese government in Khartoum cost around 2 million lives. This conflict finally resulted in a power-sharing agreement in 2005 and later saw South Sudan gain independence. In Niger, the Tuareg rebellion was the forerunner to the subsequent peace agreements in 1993 and led to Tuareg organizations receiving a share of senior positions in the central government. In Côte d'Ivoire, the violent uprising of the Mande and Voltaic in 2002 resulted in a power-sharing agreement. The Central African Republic experienced a rebellion by the Yakoma tribe in 2001, which led to their inclusion in a power- 
sharing agreement. Other examples include the Mayas, who overcame discrimination in Guatemala (1996), and the Lithuanians and Estonians, who gained regional autonomy from Russia (1957). There are more examples in Togo (1991), Chad (1991), Congo-Brazzaville (1995, 1998), Ethiopia (1992), Yugoslavia (2000), Afghanistan (2002) and Kenya (2008) of how armed struggle has helped ethnic groups to achieve political representation.

\section{Formulating a testable hypothesis}

What are the measureable implications of the proposed causal relationship between rebellion and overcoming deprivation? The hypothesis expects that, when a deprived ethnic group engages in a rebellion, the likelihood of overcoming deprivation will increase. If the causal chain works as suggested, a previous rebellion should have a statistically significant effect on an ethnic group's political status - that is, the subsequent improvement from deprived to not deprived. I therefore propose the following hypothesis:

H: Ethnic rebellion increases an ethnic group's chances of overcoming political deprivation.

\section{Data}

To test the hypothesis, this paper makes use of several data sources. Most importantly, data on politically deprived ethnic groups are drawn from the GROWup data compilation (Hunziker, 2011), which includes the EPR-ETH dataset 2.0 (Cederman et al., 2010) and data on ethnic conflict (Cunningham et al., 2009; Wucherpfennig et al., 2012).

The EPR-ETH data include all politically relevant ethnic groups living in sovereign countries (excluding colonies and failed states) with more than 500,000 inhabitants. A group is considered politically relevant and thus included in the data "if at least one political organization claims to represent it in national politics or if its members are subjected to state-led political discrimination" (Hunziker, 2011: 5-6). For the purpose of this analysis, the EPRETH dataset is preferable to the Minorities at Risk (MAR) dataset because EPR-ETH includes all politically relevant ethnic groups - both large and small — and not just mobilized minorities as is the case with the MAR dataset. In this sense, the EPR-ETH dataset overcomes the selection bias found in the MAR dataset.

The EPR-ETH dataset records the political status of each group in the respective year with a one-dimensional ordinal scale. ${ }^{5}$ The scale measures distinct states of access to federal and subregional governmental power, ranging from the most powerful groups ("monopoly", "dominant"), to nationally represented groups ("senior partner", "junior partner"), to groups only represented at the subnational level ("regional autonomy"), to groups not politically represented at all ("powerless", "discriminated") (Cederman et al., 2010: 100-101). ${ }^{6}$ The universe of cases for this analysis consists of a subsample of the EPR-ETH dataset. Given the theoretical interest in whether ethnic rebellion works for politically deprived groups, I limit the sample to ethnic groups that experienced at least one year of deprivation (i.e. status "powerless" or "discriminated") between 1946 and 2008.

The unit of analysis is group-years. As such, each observation can be uniquely described by combining the group's identification code $i$ and the year of the observation $t$. In the remainder of this section, I describe the operationalization of my hypothesis and its data sources. Table 1 shows the descriptive statistics of the variables described below. 
Table I. Descriptive statistics

\begin{tabular}{lclcc}
\hline & $(\mathrm{I})$ & $(2)$ & $(3)$ & $(4)$ \\
& Mean & Standard error & $\begin{array}{l}\text { Minimum } \\
\text { Maximum }\end{array}$ \\
\hline $\begin{array}{l}\text { Outcome variable } \\
\text { Overcoming deprivation }\end{array}$ & & & & \\
Explanatory variable & 0.0584 & $(0.235)$ & 0 & 1 \\
$\begin{array}{l}\text { Rebellion }(t-1 / 3) \\
\text { Control variables }\end{array}$ & 0.102 & $(0.302)$ & 0 & 1 \\
Rebelling groups & & & & \\
Groups in power $(\log )$ & 0.600 & $(1.543)$ & 0 & 11 \\
Military personnel pc $(\log / t-\mathrm{I})$ & 0.330 & $(0.635)$ & 0 & 2.639 \\
GDP pc (log/t $-\mathrm{I})$ & -5.867 & $(0.873)$ & -9.097 & -1.554 \\
Polity2 $(t-\mathrm{I})$ & 6.344 & $(1.488)$ & -10 & 10.62 \\
Nonviolent campaign $(t-1)$ & -1.958 & $(6.823)$ & 0 & 10 \\
Democratic change $(t-\mathrm{I})$ & 0.00185 & $(0.0430)$ & 0 & 1 \\
Observations & 0.0318 & $(0.176)$ & & 1 \\
Number of groups & 3236 & & & \\
\hline
\end{tabular}

\section{Outcome variable}

The central question of this analysis is whether rebellion is an effective strategy to overcome political deprivation. For the outcome variable, I constructed a binary variable that captures a group's change in political status from deprived to nondeprived. This variable takes the value of " 1 " when a group's political status changes from being deprived ("discriminated" or "powerless") in year ${ }_{t-1}$ to nondeprived (autonomy, junior partner, senior partner, dominance, monopoly) in the subsequent year ${ }_{t}$. The value remains " 0 " in cases where there is no change. Subsequent observations after the improvement in status are dropped from the sample, but they are reincluded in the sample in cases where a group re-experiences deprivation.

In theory, the variable's ordinal scale would allow the capture of more variation. For instance, the variable could measure whether a group jumps from being "powerless" to "monopoly" or "regional autonomy" or any other status. However, I restrict the variable's values to the deprived-nondeprived dichotomy because the argument is restricted to groups seeking to overcome deprivation, not their attempts to achieve a specific political status. The constructed variable overcoming deprivation features 227 events out of 3236 group-years.

\section{Explanatory variable}

My hypothesis suggests that engaging in violent rebellion increases the likelihood of a politically deprived ethnic group overcoming political deprivation. Hence, the independent variable measures whether an ethnic group was active in an armed conflict in which it was represented by a rebel group. Hunziker's $(2011$ : 12, 18) compilation of EPR-ETH data and other sources includes a dummy variable per group-year observation that indicates whether a group or rebel organizations connected to it were involved in an armed conflict with the government. These conflict data are based on version 4/2010 of the Armed Conflict Dataset (Gleditsch et al., 2002). I constructed the dummy variable rebellion to indicate whether the observed group had been involved in an armed conflict during the 3 years prior to an observation. A total of 330 out of 3236 group-years feature an ethnic war. I decided to use the 3 
years prior in order to account for the temporal proximity between an ongoing rebellion and the outcome variable. ${ }^{7}$ Both events (i.e. a rebellion in the 3 years prior and overcoming political deprivation) only coincide for 37 out of 164 ethnic groups, meaning that $23 \%$ of the ethnic groups that overcame political deprivation were engaged in an armed conflict during the 3 years prior to the observation. ${ }^{8}$

\section{Control variables}

Whether a deprived ethnic group achieves political rights will depend not only on a rebellion, but also on a number of additional other factors. Therefore, I include a number of other variables of theoretical importance.

Rebelling groups. Another factor that might play a role is whether a state experiences multiple rebellions. If a state has limited resources to deal with rebellions, this may have implications on the success of a rebellion. The variable rebelling groups counts the number of ongoing wars per state and year.

Group size. The size of a group is likely to be an important factor in overcoming discrimination because larger groups might be harder to suppress (Gurr, 1970) and may have distinct advantages in mobilizing recruits (Lichbach, 1995; Olson, 1965). I use the variable group size from the EPR-ETH dataset (Cederman et al., 2010) to control for this effect. Group size measures a group's relative size within the state.

Groups in power. The number of groups in power at the federal level (Cederman et al., 2010) is used as an indicator of plurality and may facilitate access for deprived groups.

Military capacity. The military capacity of the state is a factor that will be likely to influence whether a group's armed struggle to overcome political deprivation will be successful, because governments that adopt discriminatory ethnic policies (Sorens, 2010) will try to repress and eliminate insurgency movements that target the state's authority (Davenport and Inman, 2012; Davenport, 1995). The success of the state in doing so will partly depend on its military capacity. A high level of military capacity will make the territorial control of rebelling areas easier in the long term (Sepp, 2005). Only if state success becomes unlikely will the state and groups in power be willing to drop discriminatory policies and provide rights or even accommodate rebelling groups in power-sharing agreements (Luttwak, 1999). I use data from the Correlates of War's National Material Capabilities dataset (Singer, 1987), which records a state's military personnel per year. I use a lagged version of military personnel per capita to account for a delayed effect of military power.

Nonmilitary state capacity. While military capacity accounts for the coercive side of a state, it fails to account for a state's administrative and bureaucratic capacity. A strong network of state institutions is likely to implement government policies (also discriminatory ones) more effectively in remote areas of the state territory. Hendrix (2010: 274) argues that the capacity of the state to monitor its population and to identify potential insurgents and their bases is better captured by a state's bureaucratic capacity than by its military capacity. This suggests 
a shift from the state's brute force to its ability to collect and analyze information. Fearon and Laitin (2003: 79-80) suggest that, if governments knew about the bases of insurgent movements at the beginning of a conflict, it would be easier to deter such threats against the state. This ability is likely to depend on the capacity of the state in remote areas and may negatively affect a discriminated group's chances of overcoming discrimination. As a measure for the bureaucratic capacity of the state, the literature suggests using a log version of gross domestic product per capita (GDP pc). GPD per capita is highly correlated with a number of measures of bureaucratic capacity (Hendrix, 2010: 277). The GDP $p c$ variable comes from the World Bank's (2013) database.

Level of democratization. Whether a rebellion is an effective strategy or, more importantly, even necessary is influenced by the level of democratization. Democratic countries provide formal channels through which political demands can be brought forward and this is likely to have a positive effect on the probability of overcoming deprivation with nonviolent means. Discriminatory policies toward particular groups are likely to be more frequent in autocratic states than in democratic ones. While democratic states are more receptive to nonviolent protests and demands, autocratic governments are less likely to respond positively-particularly if groups demand access to state resources, territorial autonomy or even independence (Fein, 1993: 82; Fox, 1998; Gurr, 2000). It is unlikely that defamation by the international media and human rights groups or targeted sanctions would affect a relatively stable autocratic government (Desch, 2002, 2003). In such contexts, peaceful endeavors may not yield the desired success. To measure this, I use data from the Polity IV project (Marshall et al., 2010) and include a lagged Polity 2 measure to control for regime status.

Democratic change. It is not only the level of democracy that may be significant, but also the dynamic and process of democratization (Davenport, 1999). Autocratic regimes that undergo strong democratic reforms are likely to drop discriminatory policies toward certain groups. This may signal to discriminated groups that violent rebellion is not necessary to achieve political rights. On the one hand democratic change is driven to a substantial degree by domestic forces demanding political freedom, civil rights, freedom of the press and the like. Broad nonviolent movements can be the driving forces of democratic reforms and regime change (Chenoweth and Stephan, 2011). On the other hand, local politics and its dynamics are not independent from the international system. The evolution of global norms and practices and international actors affects local democratization processes through different channels (e.g. sanctions, donor pressure, human rights promotion).

Democratic transition is likely to present a rival explanation to violent rebellion. The dummy variable democratic change aims to capture such processes and takes the value of " 1 " if a country experienced a major democratic change in the previous year (Marshall et al., 2010: $35-36){ }^{9}$

Nonviolent campaigns. As addressed in the theoretical section, several recent studies find that nonviolent campaigns are generally more effective than violent ones (Chenoweth and Lewis, 2013; Chenoweth and Stephan, 2011; Shaykhutdinov, 2010). The second version of the Nonviolent and Violent Campaigns and Outcomes (NAVCO) dataset (Chenoweth and Lewis, 2013) codes 250 nonviolent and violent campaigns between 1945 and 2006. NAVCO's 
unit of analysis is the campaign and therefore cannot be directly merged with the group-level EPR-ETH data. To account for nonviolent campaigns by ethnic groups, I use a subsample of the NAVCO data. I filter those campaigns that can be linked to an ethnic group, are primarily nonviolent and do not have a radical, violent wing. ${ }^{10}$ The remaining list of nonviolent campaigns by ethnic groups (Table A8 in the Online Appendix) features 60 campaign-years of which 27 could be linked to a group-year within the EPR-ETH data. The binary variable nonviolent campaign is coded as " 1 " if a group was involved in a nonviolent campaign during the two years prior to an observation.

The other 33 campaign years could not be associated with particular ethnic groups because the campaign descriptions only referred to broad nonethnic categories (e.g. Argentina pro-democracy movement, Democracy movement in China, Greece AntiMilitary, Public Against Violence in Slovakia).

Regime categories. Following Epstein et al. (2006), I created three dummies to estimate the effect of political regime categories: autocracies $(-10-0)$, partial democracies (1-7) and full democracies (8-10).

\section{Model}

Given the binary nature of the outcome variable, I relied on logistic regressions to estimate the effects of rebellion and alternative factors on whether ethnic groups overcame political deprivation. The model utilizes group-level fixed effects to account for time-invariant unobserved group heterogeneity. The assumption here is that not all groups have the same propensity to use violence when facing deprivation. Some groups are more likely to use violence because, for instance, their cultural norms regarding the legitimacy of violence (which I do not measure) differ. By using group-level fixed effects, it is possible to account for such group-specific features, which are not randomly distributed across all groups. This approach reduces, but does not eliminate, the risk of omitted variable bias (Frees: 2010, chap. 2; Wooldridge, 2002: 412). Hence, the fixed effects estimator relies on within-group variance and omits from the analysis those variables without within-group variance. With regard to this sample, those groups that remain politically deprived for the period of observation drop out of the analysis.

Admittedly, as this analysis makes use of observational data, problems of reverse causality and omitted variables may arise and lead to biased estimates. For instance, while my hypothesis suggests that rebellion has an effect on overcoming discrimination, the opposite may be true too-specifically, discrimination may affect whether an ethnic group decides to rebel. To account for this, I use lagged versions of the explanatory variables.

Given that the yearly observations within a group are not independent from each other, the analysis needs to account for time dependence - that is, what happens to group A in the year 1998 will have an effect on what happens to group A in 1999 and so on. As suggested in the literature on time-series models, I use cubic polynomials to account for temporal dependency (Carter and Signorino, 2010). The single, square and cubic terms count the years of political deprivation per group and stop when a group changes its status to being not deprived. 


\section{Results}

Table 2 reports the results of the likelihood on overcoming deprivation. All six logistic models use group-level fixed effects. The sample covers the whole period of observation between 1946 and 2008.

Model 1 shows the results for the baseline model without the rebellion explanatory variable. The number of groups in power has, as suggested, a positive effect and is statistically significant at the $0.1 \%$ level across all models. This suggests that more inclusive governments are more likely to accommodate representatives of politically deprived ethnic groups. The military capacity of the state has a negative effect. Depending on the model specification, the significance level of military capacity varies between 5 and $0.1 \%$. The bureaucratic capacity of the state measured as GDP $p c$ is not statistically significant in any model. Both Polity2 (level of democracy) and democratic change have a positive effect. However, while the level of democracy is not statistically significant, democratic change is statistically significant at the 1 or $0.1 \%$ level. This lends support to the conventional thesis that democratic change presents an alternative route for deprived groups to achieve political rights. The variable nonviolent campaign has a negative effect but is not statistically significant in any model. This finding does not necessarily imply that nonviolent campaigns do not work in general, but that nonviolent campaigns by single ethnic groups are not successful. It is highly plausible that a significant share of the variable democratic change is influenced by broad social movements and nonviolent campaigns, as suggested by Chenoweth and Stephan (2011).

In model 2 the explanatory variable rebellion was added to the baseline model. Rebellion shows a positive effect, is statistically significant at the $0.1 \%$ level and remains robust across all models. This result is in line with the suggested causal mechanism. It is worth noting that adding rebellion barely changes the influence of the other control variables. Most importantly, the significance level of democratic change is not affected when rebellion is added. This illustrates that rebellion is an alternative mechanism.

In model 3 I added the number of rebelling groups to the model, assuming that the opportunity costs per group decrease when several groups challenge a government. The variable shows the expected positive effect and is statistically significant at $0.1 \%$. Again, the effects of the other variables hardly change.

The Polity 2 variable is dropped in models $4-6$ and replaced with dummy variables (autocracy, partial democracy and full democracy, respectively) using the coding scheme of Epstein et al. (2006). In line with the Polity 2 variable, none of these dummies is statistically significant. I also added the group size variable, which has a positive effect and is - depending on the model - statistically significant at the 1 or $0.1 \%$ level. It is worth noting that democratic change and the other variables remain robust across these models.

In sum, the following aspects are important. First, the effect of rebellion is positive and statistically significant at the $0.1 \%$ level and robust across all models. This lends strong support to the proposed hypothesis that ethnic rebellion increases the chances of overcoming political deprivation. Second, in countries with more groups in power, the chances of overcoming deprivation increase. Third, when a government is facing multiple rebellions, the chances of achieving political rights increase. Fourth, state capacity barely matters. Fifth, like violent struggle, democratic change was found to have a positive and statistically significant effect on overcoming political deprivation. 


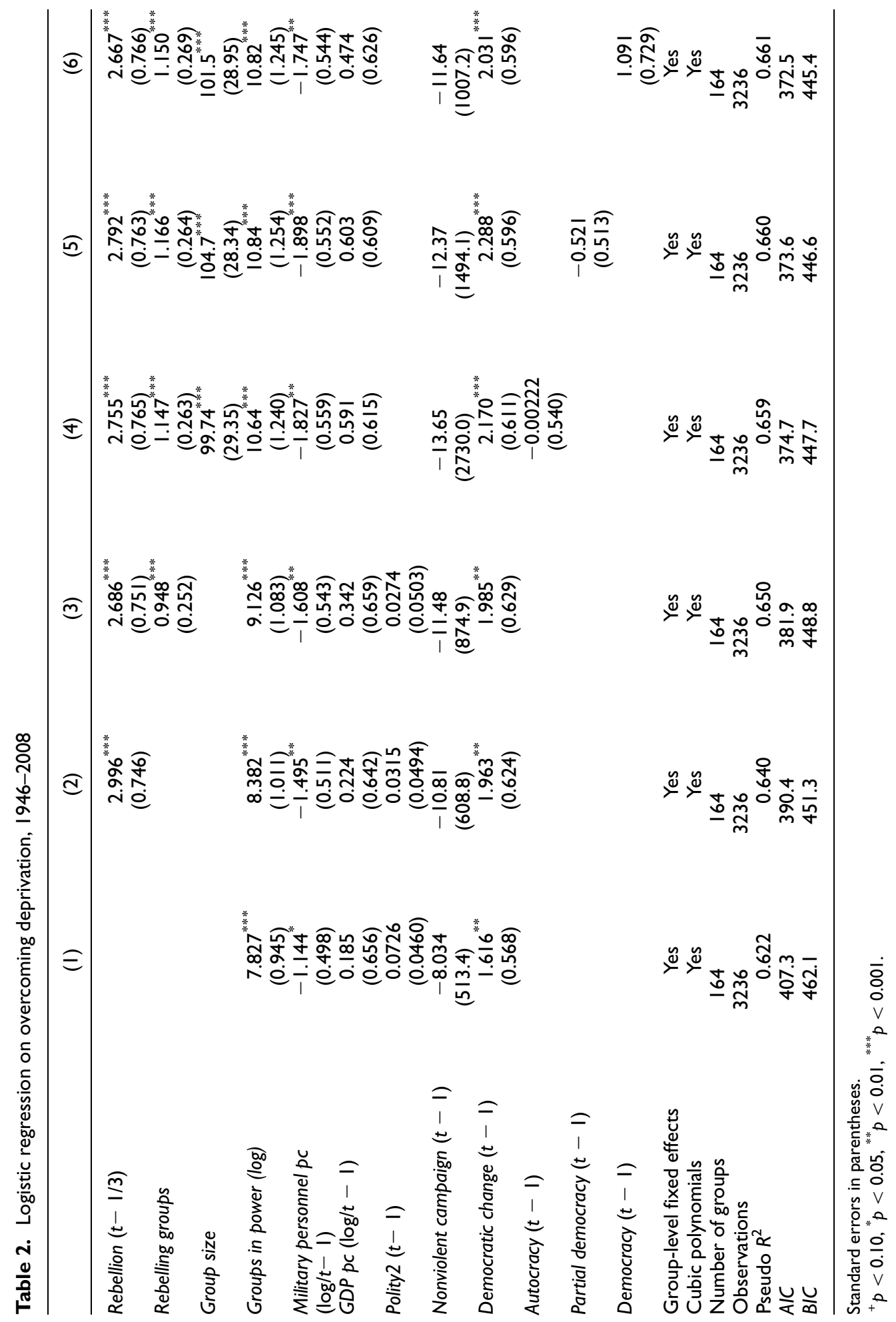


Since the effect size of the coefficients cannot be directly interpreted, I simulated the substantive effect of rebellion and democratic change on the predicted probabilities of overcoming political deprivation. ${ }^{11}$

In the baseline simulation the values of the continuous variables are set to their median. The binary variables rebellion and democratic change are set to " 0 ", suggesting that neither a rebellion nor democratic change has taken place. In this model the probability of a group overcoming deprivation is estimated at $7 \%$. The first simulation estimates the effect size of rebellion. The probability of overcoming deprivation increases to $13 \%$ when rebellion is set to " 1 ", hence the chances of overcoming deprivation almost double. In the second estimation I reset rebellion back to " 0 " and change democratic change to " 1 " to simulate the effect of a major democratic change within a nation. Unsurprisingly, the effect of a major democratic change is large: the probability of overcoming deprivation increases to $29 \%$. While these estimations should not serve as a precise scale of magnitude, they illustrate that both rebellion and democratic change have a substantial effect on overcoming deprivation different from zero. In fact, owing to endogeneity, the effect of rebellion may even be larger than estimated. Deprived groups are more likely to rebel when governments are-for whatever unobserved reasons - intransigent to accommodate group demands. While the government's intransigence should have a positive effect on rebellion, it should have negative effect on the likelihood of overcoming deprivation. Theoretically, when controlling for factors that determine government intransigence, the effect for rebellion should then be larger than estimated.

\section{Robustness checks}

To test the robustness of the results, I performed a number of additional estimations with alternative models and specifications (for tables, see the Online Appendix). The major conclusions are discussed below.

As a first robustness check, I ran the same specifications as in Table 2 without group-level fixed effects. Although the assumptions of the fixed effects model are more conservative and better suited to this analysis, it comes with a drawback as all groups that feature no variance on the dependent variable are dropped from the analysis. Therefore, I ran a random effects model to consider between-group variance in the estimation.

Table A4 in the Online Appendix shows the results for the random effects logistic models with the identical variable specifications as provided in Table 2. As we can see, the number of observations and groups in the sample is much higher than in the fixed effects model because groups showing no variation in relation to the outcome variable remain in the sample. The major results are as follows. Rebellion is, as expected, positive and statistically significant at the $1 \%$ level across all models. This suggests that unobserved heterogeneous factors do not eliminate the effect of rebellion. This is important and strengthens the robustness of the hypothesis. The number of rebelling groups does, however, lose its statistical significance. Also, group size is not statistically significance. The performance of groups in power is similar to the fixed effects models: positive and significant at $0.1 \%$. The same holds for military personnel $p c$, which remains negative and statistically significant at $5 \%$. Removing fixed effects increases the significance of $G D P p c$ up to $0.1 \%$. Most importantly, democratic change remains robust and positively significant at $0.1 \%$ across all models. Although the random effects model drastically changes the sample size and does not control for unobserved group heterogeneity, the results of the main variables remain robust. 
Table A5 shows the results for rare event logit estimations (King and Zeng, 2001). As the name suggests, this model is suited to distributions where the dependent variable has only a few positive occurrences. While this aspect is beneficial to the analysis, the model allows neither group effects nor modeling of the time-series-cross-section structure of the data. By and large, the results remain robust. The rebellion variable is positive, but its statistical significance decreases. Oddly, the number of rebelling groups and the Polity 2 index now have a negative effect. The other variables remain largely robust as described in the random effects model above.

Table A6 tests various specifications of the explanatory variable rebellion. One would theoretically assume that the effect of a rebellion on overcoming deprivation fades with an increasing time-gap between the two events. The first model corresponds to the main model 3 above and tests the effect of a rebellion taking place within an observation's previous 3 years. Model 2 tests when a group was at war not within the previous 3 years, but in the fourth, fifth or sixth previous years. Models 3 and 4 do the same for 7-10 years and 9-10 years, respectively. In resonance with the theoretical expectation, the effect of rebellion on overcoming political deprivation is only statistically significant when it takes places close to the point of overcoming political deprivation.

Further, I test for time trends in the data. Performing an augmented Dickey-Fuller test on the outcome variable overcoming deprivation results in rejecting the null hypothesis that there is a unit root $(p=0.000)$. In a next step the outcome variable's mean annual values are plotted (see Figure A1 in the Online Appendix). There does not seem to be a time trend, but there is a strong peak in the early 1980s. To test for the robustness of the earlier presented results, I run a number of additional models (see Table A9 in the Online Appendix). For comparison column 1 shows the standard fixed effects model presented earlier. Column 2 adds year dummies for the peaking years in the 1980s and the results remain largely robust. Model 3 adds dummies for 10-year period dummies for the whole observation period. Again the results remain robust. Model 4 uses first differences. Here the results of the main variables remain robust. Only the number of rebelling groups and group size lose their statistical significance.

Table A10 changes the dependent variable to years of deprivation and runs a Cox proportional hazard model. Note that, contrary to the fixed effects models, the number of observations is three times higher. The Cox model assumes that a covariate's effect of change remains constant over time. Violation of this assumption may result in biased estimates. A proportional hazard test shows the presence of nonproportionality. As suggested in Box-Steffensmeier et al. (2003), I include interaction terms between nonproportional covariates $^{12}$ and the log square-root of time. While the main variables rebellion and democratic change retain their effect direction and statistical significance others do not. This change in estimates is probably caused by the different sample size (3236 in the fixed effects model and 9036 in the Cox model) and the different dependent variables (dummy vs time spell).

Table A11 presents the results of an alternative concept of the explanatory variable rebellion. The standard rebellion variable is agnostic to the incompatibility between the ethnic group and the government. Rebellion for governance and rebellion for territory are disaggregated measures to estimate the effect of a previous rebellion. ${ }^{13}$ Again column 1 presents the standard model. Column 2 shows the effect of the rebellion for governance variable which is statistically not significant. Column 3 presents the effect of rebellion for territory which is statistically significant at $0.1 \%$. These results suggest that ethnic groups with territorial claims, 
probably in peripheral areas, are more likely to overcome political deprivation (either government inclusion or autonomy arrangements) than groups aiming for governance directly.

I perform a Wooldridge test for autocorrelation for the full model excluding the three cubic polynomials. I cannot reject the null hypothesis that there is no autocorrelation in the data $(f=0.027, p=08691)$. Further, Table A12 presents two additional models in that regard. Column 1, again, presents the standard model. Column 2 shows the estimates of a linear model (see, e.g. Angrist and Pischke, 2008 on the use of linear models for binary outcomes) that controls for level-1 autocorrelation. Column 3 presents also a linear model with Driscoll-Kraay standard errors, which assume an autocorrelated and heteroskedastic error structure. Although the estimates depart from the standard model, the main variables rebellion and democratic change remain statistically significant.

Although GDP per capita is widely used to proxy state capacity, it is a rather crude measure. Table A13 in the Online Appendix uses the relative political extraction (RPE) index by Kugler and Tammen (2012) as an alternative measure to GDP pc. RPE approximates a government's ability to raise taxes from the national output. Column 1 presents the standard model with GDP pc. Column 2 uses the square root of RPE as an alternative. In contrast to GDP pc, RPE is statistically significant at the 5\% level. All other coefficients remain robust.

In this section I described a number of robustness checks. The results are robust to a number of different models and specification and lend further support to the hypothesis that rebellion increases the probability of overcoming political deprivation. Besides these findings, the effect of democratic change has proven to be robust. Across almost all models and specifications, democratic change has a positive effect for groups attempting to overcome political discrimination and is mostly statistically significant at $0.1 \%$.

\section{Conclusion}

The literature on ethnic conflict is largely concerned with the reasons why ethnic groups rebel. Recent studies have found strong empirical evidence that excluded ethnic groups are more likely to rebel (Cederman et al., 2010, 2011; Østby et al., 2009; Østby, 2008; Stewart, 2008). However, surprisingly little attention has been paid to whether such ethnic rebellions actually have an effect on improving groups' access to political rights - that is, whether it pays off for politically deprived ethnic groups to rebel.

This paper set out to help fill this gap in the literature. The argument in this article is that violent rebellion increases the chances of ethnic groups overcoming deprivation. The argument presented is straightforward: in states where governments choose to deprive a certain populace, conventional political means of voicing demands or employing nonviolent means are less fruitful than in democratic, rather inclusive societies. Therefore, violent rebellion presents an alternative route to attaining political rights. On paper, the military power asymmetry between states and politically deprived ethnic groups suggests that a rebel victory is unlikely. As I have argued, however, politically deprived groups do not necessarily aim to defeat governments; they often seek to increase the costs of denying political participation to a point where granting political rights or autonomy arrangements becomes the cheaper option for those in power.

To illustrate this argument, I presented qualitative evidence on how the deprived Ijaw took up arms against the Nigerian government. The Ijaw resorted to violence after nonviolent protests had been repressed by state security forces. By attacking government 
facilities and oil production sites, the Ijaw were able to successfully increase costs for the Nigerian government and attain political representation.

The statistical analysis of deprived ethnic groups lends further robust support to the proposed hypothesis. Rebellion is a solid predictor of deprived groups gaining political rights. At the same time, the analysis confirms that democratic change serves as a solid alternative predictor of overcoming deprivation. Democratic change has been theorized as a rival mechanism through which deprived ethnic groups can attain rights. Democratic change does not just happen; it is likely to be driven by - among other things - broad social movements calling for civil rights, democratic transition and regime change. In this sense, democratic change may be a proxy for successful nonviolent campaigns. This speculative interpretation relates in particular to more recent studies on the effectiveness of nonviolent campaigns (see e.g. Chenoweth and Stephan, 2011).

To gain a more systematic view on the interplay between nonviolent and violent strategies in ethnic conflicts, future research would benefit from more fine-grained data on escalation processes. Such an endeavor would facilitate more rigorous testing of the assumption that violence is likely to become more viable once nonviolence has failed.

In a nutshell, political leaders in nondemocratic regimes should be aware that politically deprived groups will aim to achieve political rights. Regimes can respond to nonviolent calls for political rights with democratic change or repression. Should a state react with democratic change, this will signal that nonviolent means are effective in overcoming political deprivation. Should a state counter with repression, this will indicate that nonviolence is ineffective and lead to radicalization and rebellion, which - as shown in this analysis - may work in favor of the politically deprived.

\section{Acknowledgement}

I am grateful to Matthias Basedau, Alexander De Juan, Natascha Nisic, Johannes Vüllers and three anonymous reviewers for their helpful comments on earlier versions of this paper.

\section{Funding}

This research received no specific grant from any funding agency in the public, commercial, or not-forprofit sectors.

\section{Notes}

1. I use the definition of Cederman et al. (2010) because it complies with the data used in the quantitative analysis.

2. Besides such a motive to rebel, other factors will contribute to whether ethnic groups rebel. Notably, political entrepreneurs aiming to mobilize an ethnic rebel movement will further depend on opportunities such as popular support, rank and file recruits, finances and weapons (Fearon and Laitin, 2003; McAdam et al., 1996; McCarthy and Zald, 1977; Tilly, 1978). Without the material opportunities, grievances are unlikely to translate into a rebellion. Therefore, not all deprived groups will resort to violence. Hence, both the motive and the available opportunities will strongly determine whether an ethnic group mobilizes and rebels.

3. Wimmer et al. (2009) show that political exclusion based on ethnicity increases the risk of rebellions. Further they demonstrate that, with a large number of competing elites, the risk of infighting increases. Miodownik and Bhavnani (2011) use an agent-based model to demonstrate how 
ethnic minority rule, the degree of ethnic salience, public goods provision and resource rents affect the likelihood of conflict onset.

4. Within the subsequent quantitative analysis this case meets both conditions to be considered a typical case. First, the politically deprived Ijaw were involved in a rebellion against the Nigerian government and their rebellion led to the political inclusion of one of their representatives, Goodluck Jonathan, in the federal government.

5. See variable "1.5.43 Status_Pwrrank" (Hunziker, 2011: 23).

6. Groups may have one of the following statuses:

(1) Monopoly: the group's representatives hold absolute executive power and exclude other ethnic groups.

(2) Dominance: similar to monopoly, but members of other groups are incorporated.

(3) Senior partner: elite members of the group participate as senior partners in a powersharing agreement.

(4) Junior partner: similar to senior partner, but members hold junior positions in a power-sharing agreement.

(5) Regional autonomy: group representatives have no influence at the central government level, but some at the lower provincial or state level.

(6) Separatist autonomy: similar to regional autonomy, but indicates that the local government declared unilateral territorial independence from the central government.

(7) Powerless: representatives have no access to national or regional power, but are not explicitly discriminated against.

(8) Discriminated: group members are being actively discriminated against with the intention of excluding them from regional and national power.

7. A 3 year lag may be arbitrary. Therefore, I use a variety of alternative lags (e.g. last 5 years, last 10 years) for the explanatory variable in the section on robustness checks. All lags are robust with regard to their effect direction and statistical significance level.

8. Table A7 in the Online Appendix lists these groups.

9. Polity4's variable "regtrans" captures various degrees of regime change within a polity. The democratic change variable is coded as " 1 " if the Polity4 variable "regtrans" has a value of " 3 ", indicating an increase of 6 or more on the Polity score over a period of 3 years.

10. NAVCO features a variable called "cdivers_ethnicity", which indicates whether a campaign features ethnic diversity. In this sense ethnic diversity indicates a broad social movement. As this study looks at specific ethnic group aspects (discrimination, rebellion, political rights), I include only campaigns that do not feature ethnic diversity. Furthermore, the subsample only considers campaigns that are primarily nonviolent (prim_method) without a radical wing (rad_wing).

11. For this I use the Clarify package for Stata (King et al., 2000; Tomz et al., 2003). As Clarify only supports a limited number of statistical models, the following simulations have been performed with a standard logit model without group-level fixed effects using the variable specification of model 3 in the main regression table.

12. The $\chi^{2}$ values and ( $p$-values) of the nonproportional covariates are: Rebelling groups $=3.55$ $(0.05)$; Groups in power $=10.64(0.00)$; Military personnel $p c=4.58(0.03)$; Polity $2=7.38(0.00)$. For the global test, $\chi^{2}=23.65(0.00)$.

13. Both variables draw on the ETH-EPR dataset's variables Incidence Terr Flag and Incidence Gov Flag. 


\section{References}

Aghedo I (2012) Winning the war, losing the peace: Amnesty and the challenges of post-conflict peacebuilding in the Niger Delta, Nigeria. Journal of Asian and African Studies, August; doi: 10.1177/ 0021909612453987

Angrist JD and Pischke J-S (2008) Mostly Harmless Econometrics: An Empiricist's Companion. Princeton, NJ: Princeton University Press.

Arreguín-Toft I (2005) How the Weak Win Wars: A Theory of Asymmetric Conflict. New York: Cambridge University Press.

Box-Steffensmeier JM, Reiter D and Zorn C (2003) Nonproportional hazards and event history analysis in international relations. Journal of Conflict Resolution 47(1): 33-53; doi: $10.1177 / 0022002702239510$

Brush SG (1996) Dynamics of theory change in the social sciences relative deprivation and collective violence. Journal of Conflict Resolution 40(4): 523-545; doi: 10.1177/0022002796040004001

Buhaug H (2006) Relative capability and rebel objective in civil war. Journal of Peace Research 43(6): 691-708; doi: 10.1177/0022343306069255

Buhaug H, Cederman L-E and Gleditsch KS (2013) Square pegs in round holes: Inequalities, grievances, and civil war. International Studies Quarterly April; doi: 10.1111/isqu.12068

Carter DB and Signorino CS (2010) Back to the future: Modeling time dependence in binary data. Political Analysis 18(3): 271-292; doi: 10.1093/pan/mpq013

Cederman L-E, Wimmer A and Min B (2010) Why do ethnic groups rebel? New data and analysis. World Politics 62(1): 87; doi: 10.1017/S0043887109990219

Cederman L-E, Weidmann NB and Gleditsch KS (2011) Horizontal inequalities and ethnonationalist civil war: A global comparison. American Political Science Review 105(3): 478-495; doi: $10.1017 /$ S0003055411000207

Chenoweth E and Lewis OA (2013) Unpacking nonviolent campaigns introducing the NAVCO 2.0 dataset. Journal of Peace Research 50(3): 415-423; doi: 10.1177/0022343312471551

Chenoweth E and Stephan MJ (2011) Why Civil Resistance Works: The Strategic Logic of Nonviolent Conflict. New York: Columbia University Press.

Cunningham DE, Gleditsch KS and Salehyan I (2009) It takes two: A dyadic analysis of civil war duration and outcome. Journal of Conflict Resolution 53(4): 570-597; doi: 10.1177/002 2002709336458

Davenport C (1995) Multi-dimensional threat perception and state repression: An inquiry into why states apply negative sanctions. American Journal of Political Science 39(3): 683; doi: $10.2307 / 2111650$

Davenport C (1999) Human rights and the democratic proposition. Journal of Conflict Resolution 43(1): 92-116; doi: 10.1177/0022002799043001006

Davenport C and Inman M (2012) The state of state repression research since the 1990s. Terrorism and Political Violence 24(4): 619-634; doi: 10.1080/09546553.2012.700619

Davidheiser M and Nyiayaana K (2011) Demobilization or remobilization? The amnesty program and the search for peace in the Niger Delta. African Security 4(1): 44-64; doi: 10.1080/19392206. 2011.551063

Desch M (2002) Democracy and victory: Why regime type hardly matters. International Security 27(2): 5-47.

Desch M (2003) Democracy and victory: Fair fights or food fights? International Security 28(1): $180-194$.

Epstein DL, Bates R, Goldstone J, Kristensen I and O'Halloran S (2006) Democratic transitions. American Journal of Political Science 50(3): 551-569; doi: 10.1111/j.1540-5907.2006.00201.x

Fearon JD and Laitin DD (2003) Ethnicity, insurgency, and civil war. American Political Science Review 97(1): 75-90; doi: 10.1017/S0003055403000534 
Fearon JD and Laitin DD (2011) Sons of the soil, migrants, and civil war. World Development 39(2): 199-211; doi: 10.1016/j.worlddev.2009.11.031

Fein H (1993) Accounting for genocide after 1945: Theories and some findings. International Journal on Group Rights 1: 79.

Fox J (1998) The effects of religion on domestic conflicts. Terrorism and Political Violence 10(4): 43-63; doi: $10.1080 / 09546559808427481$

Frees E (2010) Longitudinal and Panel Data: Analysis and Applications in the Social Sciences. Cambridge: Cambridge University Press.

Ginsberg B (2013) The Value of Violence. New York: Prometheus.

Gleditsch NP, Wallensteen P, Eriksson M, Sollenberg M and Strand H (2002) Armed conflict 19462001: A new dataset. Journal of Peace Research 39(5): 615-637; doi: 10.1177/0022343302039005007

Gurr TR (1970) Why Men Rebel. Princeton, NJ: Princeton University Press.

Gurr TR (2000) Nonviolence in ethnopolitics: Strategies for the attainment of group rights and autonomy. PS: Political Science and Politics 33(2): 155; doi: 10.2307/420884

Hendrix CS (2010) Measuring state capacity: Theoretical and empirical implications for the study of civil conflict. Journal of Peace Research 47(3): 273-285; doi: 10.1177/0022343310361838

Hunziker P (2011) GrowUP Research Front-End Documentation: RFE Release 1.0. Zürich: ETH Zurich. Available at: http://www.icr.ethz.ch/data/growup/RFE_Documentation

International Crisis Group (2007) Nigeria: Ending Unrest in the Niger Delta. Abuja: International Crisis Group.

Kalyvas SN (2006) The Logic of Violence in Civil War, 1st edn. Cambridge: Cambridge University Press.

King G and Zeng L (2001) Logistic regression in rare events data. Political Analysis 9(2): 137-163.

King G, Tomz M and Wittenberg J (2000) Making the most of statistical analyses: Improving Interpretation and presentation. American Journal of Political Science 44: 347-361.

Kugler J and Tammen RL (2012) The Performance of Nations, 1st edn. Lanham, MD: Rowman \& Littlefield.

Levi M (1989) Of Rule and Revenue. Berkeley, CA: University of California Press.

Lichbach M (1995) The Rebel's Dilemma. Ann Arbor, MI: University of Michigan Press.

Luttwak EN (1999) Give war a chance. Foreign Affairs 78: 36-44.

Mack A (1975) Why big nations lose small wars: The politics of asymmetric conflict. World Politics 27(2): 175-200; doi: 10.2307/2009880

Marshall MG, Jaggers K and Gurr TR (2010) Polity IV Project. Political Regime Characteristics and Transitions, 1800-2010. Dataset Users' Manual. College Park, MD: University of Maryland, Center for International Development and Conflict Management. Available at: http://www.systemicpeace. org/polity/polity4.htm

McAdam D, McCarthy JD and Zald MN (1996) Comparative Perspectives on Social Movements: Political Opportunities, Mobilizing Structures, and Cultural Framings. Cambridge: Cambridge University Press.

McCarthy JD and Zald MN (1977) Resource mobilization and social movements: A partial theory. American Journal of Sociology 82(6): 1212-1241.

Mehler A (2009) Peace and power sharing in Africa: A not so obvious relationship. African Affairs 108(432): 453-473; doi: 10.1093/afraf/adp038

Miodownik D and Bhavnani R (2011) Ethnic minority rule and civil war onset how identity salience, fiscal policy, and natural resource profiles moderate outcomes. Conflict Management and Peace Science 28(5): 438-458; doi: 10.1177/0738894211418426

Okonta I and Douglas O (2003) Where Vultures Feast: Shell, Human Rights and Oil in the Nigerian Delta. London: Verso.

Olson M (1965). The Logic of Collective Action: Public Goods and the Theory of Groups. Cambridge, MA: Harvard University Press. 
Østby G (2008) Polarization, horizontal inequalities and violent civil conflict. Journal of Peace Research 45(2): 143-162; doi: 10.1177/0022343307087169

Østby G, Nordås R and Rød JK (2009) Regional inequalities and civil conflict in Sub-Saharan Africa. International Studies Quarterly 53(2): 301-324; doi: 10.1111/j.1468-2478.2009.00535.x

Sepp KI (2005) Best practices in counterinsurgency. Military Review 85: 8-12.

Shaykhutdinov R (2010) Give peace a chance: Nonviolent protest and the creation of territorial autonomy arrangements. Journal of Peace Research 47(2): 179-191; doi: 10.1177/0022343309353109

Singer JD (1987) Reconstructing the correlates of war dataset on material capabilities of states, 18161985. International Interactions 14(2): 115-132.

Sorens J (2010) The politics and economics of official ethnic discrimination: A global statistical analysis, 1950-2003. International Studies Quarterly 54(2): 535-560.

Stedman SJ (1997) Spoiler problems in peace processes. International Security 22: 5-53.

Stephan MJ and Chenoweth E (2008) Why civil resistance works: The strategic logic of nonviolent conflict. International Security 33(1): 7-44.

Stewart F (2008) Horizontal Inequalities and Conflict: Understanding Group Violence in Multiethnic Societies. New York: Basingstoke.

Tilly C (1978) From Mobilization to Revolution. Reading, MA: Addison-Wesley.

Tilly C (1985) War making and state making as organized crime. In: Evans PB, Rueschemeyer D and Skocpol T (eds.) Bringing the State Back In. New York: Cambridge University Press.

Toft MD (2009) Securing the Peace: The Durable Settlement of Civil Wars. Princeton, NJ: Princeton University Press.

Tomz M, Wittenberg J and King G (2003) CLARIFY: Software for Interpreting and Presenting Statistical Results. Version 2.1. Stanford University, University of Wisconsin, and Harvard University. Available at: http://scholar.harvard.edu/gking/clarify.

Tull DM and Mehler A (2005) The hidden costs of power-sharing: Reproducing insurgent violence in Africa. African Affairs 104(416): 375-398; doi: 10.1093/afraf/adi034

Ukiwo U (2007) From "pirates" to "militants": A Historical perspective on anti-state and anti-oil company mobilization among the Ijaw of Warri, Western Niger Delta. African Affairs 106(425): 587-610; doi: 10.1093/afraf/adm057

Ukiwo U (2011) The Nigerian state, oil and the Niger Delta crisis. In: Obi C and Rustad SA (eds) Oil and Insurgency in the Niger Delta: Managing the Complex Politics of Petroviolence. New York: Zed Books, pp. 17-27.

UNDP (2006) Niger Delta Human Development Report. United Nations Development Programme

Walter BF (2006) Building reputation: Why governments fight some separatists but not others. American Journal of Political Science 50(2): 313-330.

Watts M and Ibaba IS (2011) Turbulent oil: Conflict and insecurity in the Niger Delta. African Security 4(1): 1-19; doi: 10.1080/19392206.2011.563181

Weinstein JM (2005) Resources and the information problem in rebel recruitment. Journal of Conflict Resolution 49(August): 598-624; doi: 10.1177/0022002705277802

Wimmer A, Cederman L-E and Min B (2009) Ethnic politics and armed conflict: A configurational analysis of a new global data set. American Sociological Review 74(2): 316-337; doi: $10.1177 / 000312240907400208$

Wooldridge JM (2002) Econometric Analysis of Cross Section and Panel Data. Cambridge, MA: MIT Press.

World Bank (2013) World Bank Development Indicators, GDP per Capita.

Wucherpfennig J, Metternich NW, Cederman L-E and Gleditsch KS (2012) Ethnicity, the state, and the duration of civil war. World Politics 64(1): 79-115. 